\title{
PENGARUH KUALITAS PRODUK, HARGA DAN PROMOSI TERHADAP KEPUTUSAN PEMBELIAN KOSMETIK LAMER PADA MALL METRO PACIFIC PLACE
}

\author{
Bernadet Kuswinar \\ Lucy Nancy Simatupang \\ Email : mamaolgalucy@yahoo.co.id
}

\begin{abstract}
The problem in this study wanted to find out the factors that can influence about quality of the product, price, promotion for purchasing decisions of customers in buying cosmetics Lamer at the Metro Mall Pacific Place. The data collected using the formula Roscoe with spread 80 respondents which is Lamer cosmetics customers. Metodology this research is causal relations with test validity, reliability test, test, test the classical asumption corelletion, multiple linear regression, $t$-test, F-test, and determinants. Based on the results of research partially known that Product quality $\left(X_{1}\right)$, Price $\left(X_{2}\right)$, Promotion $\left(X_{3}\right)$ decision to purchase cosmetics Lamer. The quality of the Product, Price, Promotion of the simultaneous effect on purchasing decisions.
\end{abstract}

Keywords : Quality of the product $\left(X_{1}\right)$, Price $\left(X_{2}\right)$, Promotion $\left(X_{3}\right)$, Purchase decisions $(Y)$.

\section{PENDAHULUAN}

Permintaan akan kebutuhan perawatan kulit wajah dan tubuh ini akan terus meningkat seiring dengan kepedulian akan perawatan kulit wajah dan tubuh dari kaum sosialita, pengusaha dan kaum jetset dalam memenuhi kebutuhan dan keinginan mereka untuk tampil lebih mewah. Dalam hal ini La Mer dapat menawarkan perawatan untuk kulit wajah dan tubuh secara mewah sehingga dapat memenuhi keinginan dan kebutuhan perawatan kulit wajah dan tubuh untuk kaum sosialita, pengusaha dan kaum jetset. La Mer adalah salah satu perusahaan ritel impor perawatan kulit wajah dan tubuh yang sangat mewah dan memiliki kualitas produk yang sangat bagus, yang pertama kali diciptakan di America pada tahun 1965.

Produk La Mer adalah produk yang menawarkan kualitas secara ajaib dengan desain, harga dan nilai yang sangat mewah dalam tiap bahan-bahan dari produknya yang dapat memenuhi kebutuhan, keinginan, selera dan gaya hidup kaum sosialita, pengusaha dan kaum jetset. Secara beruntun adanya perubahan perilaku konsumen membuat

pemasar untuk lebih teliti dan dinamis dalam memahami kebutuhan dan keinginan konsumennya dimasa sekarang dan masa depan. Di La Mer Metro Pacific Place penjualan La Mer mengalami kenaikan dan penurunan tiap tahunnya. Berdasarkan data dari penjualan kosmetik La Mer di Metro Pacific Place, berikut data penjualan kosmetik La Mer di tahun 2014-2016: 
Tabel 1

Penjualan Kosmetik La Mer di Metro Pacific Place tahun 2014-2016

\begin{tabular}{|c|c|c|c|c|}
\hline Merek & 2014 & 2015 & 2016 & Total \\
\hline La Mer & 4.800 .000 .000 & 4.200 .000 .000 & 6.000 .000 .000 & 15.000 .000 .000 \\
& & & & \\
\hline Esteelauder & 1.800 .000 .000 & 1.440 .000 .000 & 2.400 .000 .000 & 5.640 .000 .000 \\
\hline Kanebo & 2.400 .000 .000 & 3.000 .000 .000 & 3.600 .000 .000 & 9.000 .000 .000 \\
\hline \multicolumn{4}{|c|}{ Sumber : Laporan Penjualan Kosmetik di Metro Pacific Place }
\end{tabular}

Keputusan pembelian merupakan suatu keputusan sebagai pemilikan suatu tindakan dari dua atau lebih pilihan alternatif. Setiap orang pasti pernah mempertimbangkan suatu hal sebelum melakukan keputusan pembelian perawatan wajah dan tubuh. Apakah produk yang dibeli sudah sesuai dengan kebutuhan atau keinginannya? Produk yang akan dibeli apakah sudah sesuai dengan kondisi dirinya? Namun terkadang orang tidak mempertimbangkan sesuatu hal sebelum melakukan pembelian. Sebelum membeli konsumen terlebih dahulu akan melakukan beberapa alternatif pilihan, apakah akan membeli atau tidak. Jika konsumen kemudian memutuskan salah satunya, maka konsumen sudah melakukan keputusannya. Teori mengatakan keputusan pembelian merupakan tugas pemasar adalah memahami perilaku konsumen pada setiap tahap karena perilaku konsumen menentukan proses pengambilan keputusan dalam pembelian suatu produk.

Untuk memahami pembuatan keputusan pembelian konsumen, terlebih dahulu harus dipahami sifat-sifat keterlibatan konsumen dan memahami tingkat keterlibatan konsumen terhadap produk berarti pemasar berusaha mengidentifikasi faktor-faktor yang menyebabkan seseorang dapat melakukan keputusan pembelian. Salah satu faktor yang dapat menentukan keputusan pembelian terhadap produk kosmetik La Mer ini adalah kualitas produk. Maka Lamer memiliki kualitas produk yang dapat membantu untuk mengatasi masalah pada kulit wajah dan badan. Lamer terbuat dari bahan yang sangat berkualitas, tediri dari sea kelp yang diambil di lautan California, Vancouver, yang dapat memberikan manfaat untuk melembapkan, mencerahkan, membantu meregenerasikan kulit, menghaluskan dan dapat menyembuhkan kulit saat kulit mengalami masalah seperti kemerahan, sensitif, mengobati bekas luka bakar dan flek hitam pada kulit. Teori mengatakan kualitas produk merupakan kemampuan suatu barang untuk memberikan hasil atau kinerja yang sesuai bahkan melebihi dari apa yang di inginkan pelanggan. Oleh karena itu perusahaan berusaha memfokuskan pada kualitas produk dan membandingkannya dengan produk yang ditawarkan oleh perusahaan pesaing.

Dalam menentukan keputusan terdapat juga faktor harga. Di era modern sekarang ini, orang sudah mampu bertindak logis sehingga akan lebih selektif terhadap pembelian produk kosmetik. Untuk itu strategi penetapan harga yang digunakan antara perusahaan yang satu dengan yang lain berbeda dikarenakan pelaksanaan suatu strategi harus disesuaikan dengan kondisi dan tujuan yang ingin dicapai perusahaan tersebut. Hal ini dilakukan oleh perusahaan untuk dapat menarik konsumen agar dapat membeli, menggunakan dan loyal terhadap produk kosmetik yang dijual oleh perusahaan tersebut.

Harga yang diterapkan Lamer di Indonesia merupakan harga yang mampu bersaing dengan harga Lamer yang ada di luar nergri. Harga Lamer sangatlah tinggi dibandingkan dengan kosmetik lainnya yang ada di Indonesia. Dalam menerapkan harga Lamer di Indonesia rata-rata yang dijual lebih mahal dibandingkan dengan harga Lamer di luar negri, maka Lamer memiliki strategi harga yaitu pelanggan dapat membeli Lamer dengan minimal pembelanjaan Rp 5.000.000 mendapatkan potongan langsung sebesar $10 \%$. 
Dengan ini, pelanggan dapat menjadi loyal untuk terus berbelanja di Indonesia walaupun dengan harga yang lebih mahal, contohnya dengan pembelian Lamer dapat dicicil, dengan membeli Lamer di Indonesia, pelanggan mendapatkan gratis spa di Hotel Four Seassons, Hotel Raffles dan Hotel Shangrilla. Teori mengatakan harga merupakan salah satu elemen perusahaan yang menghasilkan pendapatan, elemen lain menghasilkan biaya. Harga juga megkomunikasikan posisitioning nilai yang dimaksud dalam produk atau merek ke pasar. Produk dapat dirancang dan dipasarkan dengan baik dapat dijual dengan harga tinggi dan menghasilkan laba yang besar. Penetapan harga harus diimbangi dengan pemasaran yang baik dan menarik.

Dalam menentukan keputusan pembelian terdapat juga faktor promosi. Keputusan konsumen untuk membeli atau tidak terhadap suatu produk. Dengan melakukan promosipromosi yang menarik dan membedakan dengan pesaingnya maka akan menarik konsumen baru atau konsumen pelanggannya untuk melakukan pembelian produk. Promosi yang membedakan LA MER dengan perusahaan cosmetik impor lainnya adalah LA MER dalam launching produk barunya selalu mengadakan Beauty Work Shop di Hotel bintang 5 di jakarta, seperti di Hotel Ritz Carlton, Hotel Mulia, Hotel Four Seassons, Hotel Fairmont dan di Hotel Ciputra Surabaya.

Dimana disana di ulas semua informasi mengenai produk baru, cara pakai produk LA MER secara keseluruhan, demonstation produk, service facial, service hand massage, dan tentunya promo yang menarik yaitu potongan harga serta welcome gift berupa 1 set sample atau gift product senilai harga asli dari product tersebut tentunya sesuai mekanisme pembelanjaan yang telah ditentukan. LA MER juga mengundang artis sebagai bintang tamu serta dihadiri oleh rekan-rekan media serta pelanggan lamer dari kaum sosialita, pengusaha, kaum jetset. Promosi merupakan salah satu faktor penentu suatu program pemasaran. Teori mengatakan promosi adalah suatu bentuk komunikasi pemasaran. Yang dimaksud komunikasi pemasaran adalah aktivitas pemasaran yang berusaha menyebarkan informasi mempengaruhi atau membujuk, dan atau mengingatkan pasar sasaran atas perusahaan dan produknya agar bersedia menerima, membeli dan loyal pada produk yang ditawarkan perusahaan yang bersangkutan. Melalui pemasaran konsumen dapat mengetahui promosi-promosi yang ditawarkan, dengan promosi tersebut perusahaan dapat menarik konsumen baru dan mempertahankan konsumen yang sudah berlangganan sehingga konsumen tersebut menjadi sangat loyal terhadap produk yang digunakannya. Promosi adalah upaya untuk memberitahu atau menawarkan produk dengan tujuan menarik calon konsumen untuk membeli. Berikut ini adalah peneliti-peneliti sebelumnya yang relevan.

Tabel 2

Research Gap

\begin{tabular}{|c|l|l|}
\hline Variabel & \multicolumn{1}{|c|}{ Peneliti } & \multicolumn{1}{|c|}{ Hasil Penelitain } \\
\hline \multirow{5}{*}{ Kualitas Produk } & $\begin{array}{l}\text { Afrianti Novita Anwar dan } \\
\text { Erpiawan (2015) }\end{array}$ & $\begin{array}{l}\text { Tidak berpengaruh terhadap keputusan } \\
\text { pembelian }\end{array}$ \\
\cline { 2 - 3 } & Geofani Da Costa Jong (2015) & $\begin{array}{l}\text { Berpengaruh terpengaruh terhadap } \\
\text { keputusan pembelian }\end{array}$ \\
\cline { 2 - 4 } & Jackson R.S Weenas (2013) & $\begin{array}{l}\text { Berpengaruh terhadap keputusan } \\
\text { pembelian }\end{array}$ \\
\cline { 2 - 4 } & Doni Hariadi (2013) & $\begin{array}{l}\text { Berpengaruh terhadap keputusan } \\
\text { pembelian }\end{array}$ \\
\hline \multirow{3}{*}{ Harga } & $\begin{array}{l}\text { Afrianti Novita Anwar dan } \\
\text { Erpiawan (2015) }\end{array}$ & $\begin{array}{l}\text { Tidak berpengaruh terhadap keputusan } \\
\text { pembelian }\end{array}$ \\
\cline { 2 - 3 } & Geofani Da Costa Jong (2015) & Tidak berpengaruh terhadap keputusan \\
\hline
\end{tabular}




\begin{tabular}{|c|c|c|}
\hline & & pembelian \\
\hline & Geofani Da Costa Jong (2015) & $\begin{array}{l}\text { Tidak berpengaruh terhadap keputusan } \\
\text { pembelian }\end{array}$ \\
\hline & Jackson R.S Weenas (2013) & $\begin{array}{l}\text { Berpengaruh terhadap keputusan } \\
\text { pembelian }\end{array}$ \\
\hline & Doni Hariadi (2013) & $\begin{array}{l}\text { Berpengaruh terhadap keputusan } \\
\text { pembelian }\end{array}$ \\
\hline \multirow{4}{*}{ Promosi } & $\begin{array}{llll}\text { Afrianti Novita } & \text { Anwar dan } \\
\text { Erpiawan (2015) } & & \end{array}$ & $\begin{array}{l}\text { Berpengaruh terhadap keputusan } \\
\text { pembelian }\end{array}$ \\
\hline & Geofani Da Costa Jong (2015) & $\begin{array}{l}\text { Tidak berpengaruh terhadap keputusan } \\
\text { pembelian }\end{array}$ \\
\hline & Jackson R.S Weenas (2013) & $\begin{array}{l}\text { Berpengaruh terhadap keputusan } \\
\text { pembelian }\end{array}$ \\
\hline & Doni Hariadi (2013) & $\begin{array}{l}\text { Berpengaruh terhadap keputusan } \\
\text { pembelian }\end{array}$ \\
\hline \multirow{4}{*}{$\begin{array}{l}\text { Keputusan } \\
\text { Pembelian }\end{array}$} & $\begin{array}{l}\text { Afrianti Novita Anwar dan } \\
\text { Erpiawan (2015) }\end{array}$ & $\begin{array}{l}\text { Berpengaruh terhadap keputusan } \\
\text { pembelian }\end{array}$ \\
\hline & Geofani Da Costa Jong (2015) & $\begin{array}{l}\text { Berpengaruh terhadap keputusan } \\
\text { pembelian }\end{array}$ \\
\hline & Jackson R.S Weenas (2013) & $\begin{array}{l}\text { Berpengaruh terhadap keputusan } \\
\text { pembelian }\end{array}$ \\
\hline & Doni Hariadi (2013) & $\begin{array}{l}\text { Berpengaruh terhadap keputusan } \\
\text { pembelian }\end{array}$ \\
\hline
\end{tabular}

Sumber : data diolah 2017

Berdasarkan fenomena yang ada dan masih adanya perbedaan hasil penelitian sebelumnya maka penelitian selanjutnya terkait variabel apa saja yang mampu mempengaruhi keputusan pembelian.

\section{KERANGKA PEMIKIRAN TEORITIS}

Berbagai faktor diidentifikasi mampu mempengaruhi Keputusan Pembelian adalah :

1. Kualitas Produk. Kualitas Produk adalah totalitas fitur dan karakteristik dari produk atau jasa yang dinilai kemampuannya untuk memuaskan kebutuhan konsumen, baik yang dinyatakan atau secara tersirat.

2. Harga. Harga adalah sejumlah uang yang dibebankan atas suatu produk atau jasa atau jumlah dari nilai yang ditukar konsumen atas manfata-manfaat karena memiliki atau menggunakan produk tersebut.

3. Promosi. Promosi adalah berbagai cara untuk menginformasikan, membujuk dan menginginkan konsumen secara langsung maupun tidak langsung tentang suatu produk atau brand yang dijual.

\section{Dimensi Kualitas Produk}

1. Keunggulan produk : mempunyai keunggulan melembabkan kulit, dapat mencerahkan kulit, dapat menyembuhkan kulit, pembuatannya dengan fermentasi

2. Kualitas produk: bahan baku dari ganggang laut, cara pembuatannya menggunakan tangan, bahan baku dibuat dengan bantuan cahaya dan suara

3. Desain: kemasan yang tidak mudah pecah, kemasan ekslusif, kemasaran yang mudah dibawa

4. Variasi produk: dapat dipakai pagi, malam, membantu untuk memenuhi kebutuhan kulit, seri mencerahkan yang lengkap

5. Daya tahan: produk dapat dipakai diiklim apapun, aroma wangi lembut, terdapat tanggal kadarluarsa. 


\section{Dimensi Harga}

1. Daftar harga: harga yang bersaing, harga sesuai dengan kualitas produk, harga yang ekslusif

2. Potongan harga: pemberian diskon dengan minimal pembelajaan, diskon $10 \%$, diskon $20 \%$

3. Sistem pembayaran: membayar dengan cara dicicil, pembayaran secara tunai.

\section{Dimensi Promosi}

1. Advertising (periklanan) yaitu "semua bentuk presentasi dan promosi nonpersonal yang dibayar oleh sponsor untuk mempresentasikan gagasan, barang atau jasa". Periklanan dianggap sebagai manajemen citra yang bertujuan menciptakan dan memelihara cipta dan makna dalam benak konsumen. Bentuk promosi yang digunakan mencakup broadcast, print, internet, outdoor, dan bentuk lainnya.

2. Sales promotion (promosi penjualan), yaitu insentif-insentif jangka pendek untuk mendorong pembelian atau penjualan suatu produk atau jasa. Bentuk promosi yang digunakan mencakup discounts, coupons, displays, demonstrations, contests, sweepstakes, dan events.

3. Personal selling (penjualan perseorangan), yaitu presentasi personal oleh tenaga penjualan dengan tujuan menghasilkan penjualan dan membangun hubungan dengan konsumen. Bentuk promosi yang digunakan mencakup presentations, trade shows, dan incentive programs.

4. Personal selling (penjualan perseorangan), yaitu presentasi personal oleh tenaga penjualan dengan tujuan menghasilkan penjualan dan membangun hubungan dengan konsumen. Bentuk promosi yang digunakan mencakup presentations, trade shows, dan incentive programs.

5. Public relations (hubungan masyarakat), yaitu membangun hubungan yang baik dengan berbagai publik perusahaan supaya memperoleh publisitas yang menguntungkan, membangun citra perusahaan yang bagus, dan menangani atau meluruskan rumor, cerita, serta event yang tidak menguntungkan. Bentuk promosi yang digunakan mencakup press releases, sponsorships, special events, dan web pages.

6. Direct marketing (penjualan langsung), yaitu hubungan langsung dengan sasaran konsumen dengan tujuan untuk memperoleh tanggapan segera dan membina hubungan yang abadi dengan konsumen. Bentuk promosi yang digunakan mencakup catalogs.

Tabel 3

Penelitian Terdahulu yang Relevan

\begin{tabular}{|c|c|c|c|c|}
\hline Tahun & Peneliti & Variabel & Alat Analisis & Hasil Penelitian \\
\hline 2013 & Doni Hariadi & $\begin{array}{l}\text { Independen: } \\
\text { Produk, } \\
\text { harga, promosi, } \\
\text { distribusi } \\
\text { Dependen: } \\
\text { Keputusan } \\
\text { pembelian }\end{array}$ & $\begin{array}{l}\text { Analisis } \\
\text { Regresi Linier } \\
\text { Berganda }\end{array}$ & $\begin{array}{l}\text { Produk berpengaruh terhadap keputusan } \\
\text { pembelian, harga berpengaruh terhadap } \\
\text { keputusan pembelian, promosi } \\
\text { berpengaruh terhadap keputusan } \\
\text { pembelian, distribusi berpengaruh } \\
\text { terhadap keputusan pembelian }\end{array}$ \\
\hline 2013 & $\begin{array}{ll}\text { Jackson R.S. } \\
\text { Weenas }\end{array}$ & $\begin{array}{l}\text { Independen: } \\
\text { Kualitas Produk, } \\
\text { Harga, Promosi, } \\
\text { dan } \quad \text { Kualitas } \\
\text { Pelayanan } \\
\text { Dependen: } \\
\text { Keputusan } \\
\text { pembelian }\end{array}$ & $\begin{array}{l}\text { Analisis } \\
\text { Regresi } \\
\text { Berganda }\end{array}$ & $\begin{array}{l}\text { Kualitas Produk berpengaruh terhadap } \\
\text { keputusan pembelian, Harga berpengaruh } \\
\text { terhadap keputusan pembelian, Promosi } \\
\text { berpengaruh terhadap keputusan } \\
\text { pembelian, Kualitas Pelayanan terhadap } \\
\text { berpengaruh terhadap keputusan } \\
\text { pembelian }\end{array}$ \\
\hline 2015 & Afrianti & Independen : & Analisis & berpengaruh \\
\hline
\end{tabular}




\begin{tabular}{|c|c|c|c|c|}
\hline & $\begin{array}{l}\text { Novita Anwar } \\
\text { dan Erpiawan }\end{array}$ & Harga dan promosi & $\begin{array}{l}\text { Regresi } \\
\text { Berganda }\end{array}$ & 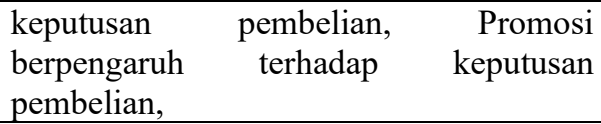 \\
\hline 2015 & $\begin{array}{l}\text { Geofanni Da } \\
\text { Costa Jong }\end{array}$ & $\begin{array}{l}\text { Independen: } \\
\text { Pengaruh Kualitas } \\
\text { Produk, Promosi } \\
\text { dan Harga } \\
\text { Dependen: } \\
\text { Keputusan } \\
\text { pembelian }\end{array}$ & $\begin{array}{l}\text { Analisis } \\
\text { Regresi } \\
\text { Berganda }\end{array}$ & $\begin{array}{l}\text { Kualitas produk berpengaruh terhadap } \\
\text { keputusan pembelian, } \\
\text { berpengaruh terhadap } \\
\text { pembelian, harga tidak berpengaruh } \\
\text { terhadap keputusan pembelian }\end{array}$ \\
\hline
\end{tabular}

Sumber : diolah oleh penulis 2017

Berdasarkan penjelasan diatas maka dapat dikembangkan kerangka pemikiran teoritis seperti di bawah ini:

\section{Gambar 1}

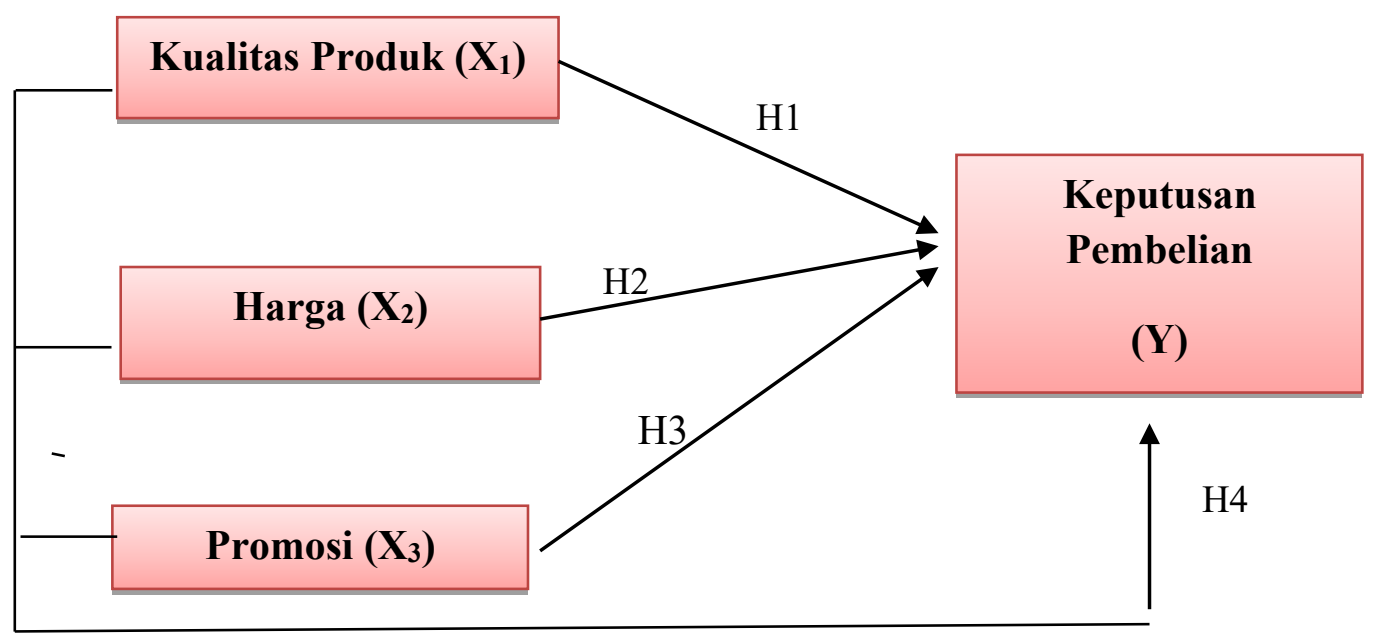

Hipotesis yang diajukan dalam penelitian ini adalah:

Hipotesis 1 :

Ho $\quad:$ Kualitas Produk tidak berpengaruh terhadap Keputusan Pembelian

$\mathrm{Ha} \quad$ : Kualitas Produk berpengaruh terhadap Keputusan Pembelian

Hipotesis 2 :

Ho $\quad$ : Harga tidak berpengaruh terhadap Keputusan Pembelian

$\mathrm{Ha} \quad$ : Harga berpengaruh terhadap Keputusan Pembelian

Hipotesis 3 :

Ho : Promosi tidak berpengaruh terhadap Keputusan Pembelian

$\mathrm{Ha} \quad$ : Promosi berpengaruh terhadap Keputusan Pembelian

Hipotesi 4 :

Ho

: Kualitas Produk, Harga, Promosi secara simultan tidak berpengaruh terhadap Keputusan Pembelian

Ha : Kualitas Produk, Harga, Promosi secara simultan berpengaruh terhadap

Keputusan Pembelian

\section{METODE}

\section{Populasi dan Sampel}

Populasi adalah wilayah generalisasi yang terdiri atas obyek atau subyek yang mempunyai kualitas dan karakteristik tertentu yang ditetapkan oleh peneliti untuk 
dipelajari dan kemudian ditarik kesimpulannya. Populasi dalam penelitian ini adalah seluruh konsumen yang membeli kosmetik Lamer di Mall Metro Pacific Place.

\section{Sampel}

Jumlah sampel yang digunakan dalam penelitian ini menggunakan rumus

Roscoe(Sugiono 2016 : 90):

$\mathrm{n}=(10-4) \mathrm{k}(10.4)=40$

Keterangan :

$\mathrm{n}=$ Jumlah Sampel

$\mathrm{k}=$ Jumlah variabel independen dalam penelitian

Jumlah sampel yang digunakan dalam penelitian ini adalah 80 responden

\section{Desain Penelitian}

Dalam penelitian ini desain pnelitian yang digunakan yaitu Penelitian Kausal, yaitu penelitian yang bertujuan untuk mengetahui pengaruh antara satu atau lebih variabel independen terhadap variabel dependen

\section{Jenis dan sumber data}

Data primer adalah sumber data yang langsung memberikan data kepada pengumpul data. Data primer dalam penelitian ini yaitu data yang pertama kali dicatat dan dikumpulkan oleh peneliti. Data primer yang diperoleh peneliti dengan cara pengisian kuesioner oleh responden.

\section{Metode Analisis data}

1.Analisis deskriptif

Metode analisis deskriptif merupakan metode yang digunakan untuk menganalisis data-data tersedia dan diolah sehingga diperoleh gambaran yang jelas mengenai fakta-fakta fenomena yang diteliti.

2.Analisis Regresi Linear Berganda

Model Regresi linear dikatakan sebagai model yang baik hanya jika model tersebut memenuhi asumsi-asumsi klasik yaitu data residual terdistribusi normal, tidak adanya multikolinieritas, autokorelasi dan heterokedasitas.

\section{Metode Pengujian Data \\ Uji Validitas}

Uji validitas item adalah merupakan uji instrumen data untuk mengetahui seberapa cermat suatu item dalam mengukur apa yang ingin diukur. Uji validitas yang digunakan dalam penelitian ini menggunakan Metode Corrected Item- Total Correlation dengan cara mengkorelasikan masing-masing indicator.

1. Jika $\mathrm{r}$ hitung $\geq \mathrm{r}$ tabel, maka butir pertanyaan atau variabel valid.

2. Jika $r$ hitung $>r$ tabel, maka butir pertanyaan atau variabel tidak valid.

\section{Uji Reliabilitas}

Uji reliabilitas digunakan untuk mengetahui konsistensi alat ukur yang biasanya menggunakan kuesioner. Maksudnya apakah alat ukur tersebut akan mendapatkan pengukuran yang tetap konsisten jika pengukuran diulang kembali. Metode yang dipakai dalam pengujian reliabilitas adalah dengan menggunakan metode Cronbach Alpha yang dimana satu variabel dianggap reliabel jika cronbach alpha $>0,6$.

\section{Uji Normalitas Data}

Model regresi yang baik adalah yang memiliki nilai residual yang terdistribusi secara normal. dengan melihat penyebaran data pada sumber diagonal pada grafik normal $P-P$ Plot of Regression Standardized Residual atau model One Sample Kolmogorov-Smirnov dengan nilai signifikansi lebih dari 0,05. Dasar pengambilan keputusan pada uji normalitas ini adalah sebagai berikut : 
1. Jika angka signifikansi Uji Kolmogrov - Smirnov $\geq 0,05$ maka data berdistribusi normal

2. Jika angka signifikansi Uji Kolmogrov - Smirnov $<0,05$ maka data berdistribusi tidak normal

\section{Uji Asumsi Klasik}

\section{Uji Normalitas Residual}

Normalitas data merupakan syarat pokok yang harus dipenuhi dalam analisis parametrik. Normalitas data merupakan hal yang paling penting karena dengan data yang terdistribusi normal, maka data tersebut dapat dianggap mewakili populasi. Uji Normalitas pada model regresi digunakan untuk menguji apakah nilai residual yang terdistribusi secara secara normal atau tidak. Model regresi yang baik adalah yang memiliki nilai residual yang terdistribusi secara normal. Beberapa metode uji normalitas, yaitu dengan melihat penyebaran data pada sumber diagonal pada grafik Normal P-Plot Of regression standardized residual atau dengan uji One Sample Kologorov-Smirnov, yaitu dengan melihat angka nilai signifikansinya lebih dari 0,05

\section{Uji Multikolinieritas}

Multikolinieritas artinya antar variabel independen yang terdapat dalam model regresi memiliki hubungan linear yang sempurna atau mendekati sempurna (koefisien korelasinya tinggi atau bahkan 1). Model regresi yang baik seharusnya tidak terjadi korelasi sempurna atau mendekati sempurna diantara variabel bebasnya. Konsekuensi adanya multikolinieritas adalah koefisien korelasi tidak tertentu dan kesalahan menjadi sangat besar.Metode uji multikolinieritas yaitu melihat nilai variance inflation factor (VIF), apabila nilai VIF $<10$ dan Tolerance $>0,1$, maka dinyatakan tidak terjadi multikolinieritas.

\section{Uji Autokorelasi}

Uji autokorelasi adalah merupakan korelasi antara anggota observasi yang disusun menurut waktu atau tempat. Metode pengujian menggunakan uji Durbin-Watson (DW test).

Pengambilan keputusan pada uji Durbin-Watson sebagi berikut :

1. DU $<$ DW < 4-DU maka Ho diterima, artinya tidak terjadi autokorelasi

2. $\mathrm{DW}<\mathrm{DL}$ atau DW $>$ 4-DL maka Ho ditolak, artinya terjadi autokorelasi

3. $\mathrm{DL}<\mathrm{DW}<\mathrm{DU}$ atau 4-DU $<\mathrm{DW}<4-\mathrm{DL}$, artinya tidak ada kepastian atau kesimpulan yang pasti.

\section{Uji Heteroskedastisitas}

Heteroskedastisitas merupakan varian residual yang tidak sama pada semua pengamatan di dalam model regresi. Regresi yang baik seharusnya tidak terjadi heteroskedastisitas. Uji heterokedastisitas bertujuan untuk menguji apakah dalam model regresi terjadi ketidaksamaan variance dari residual satu pengamatan kepengamatan yang lain. Dasar kriteria pengambilan keputusan : jika ada pola tertentu titik-titik yang ada membentuk suatu pola tertentu yang teratur (bergelombang, melebar, kemudian menyempit), maka terjadi heteroskedastisitas. Jika tidak ada pola yang jelas, seperti titik-titik menyebar diatas dan dibawah angka 0 pada sumbu Y, maka tidak terjadi heteroskedastisitas.

\section{Pengujian Hipotesis}

1. Analisis Korelasi

Analisis Korelasi merupakan suatu analisis yang digunakan untuk mengetahui ada atau tidaknya hubungan yang signifikan antara variabel dependen dengan variabel-variabel 
independen. Teknik analisis korelasi Pearson Product Moment termasuk teknik statistik parametrik yang menggunakan data interval dan ratio dengan persyaratan tertentu.

Tabel 4

Interprestasi Koefisien Korelasi

\begin{tabular}{|l|l|}
\hline \multicolumn{1}{|c|}{ Indeks Korelasi } & Penafsiran \\
\hline $0,00-0,199$ & Sangat Rendah \\
\hline $0,20-0,399$ & Rendah \\
\hline $0,40-0,599$ & Sedang \\
\hline $0,60-0,799$ & Kuat \\
\hline $0.80-1,000$ & Sangat Kuat \\
\hline
\end{tabular}

Untuk melakukan pengujiannya, kriterianya adalah sebagai berikut:

1.Jika Pearson Correlation bernilai positif, maka hubungan yang terjadi searah

2.Jika Pearson Correlation bernilai negatif, maka hubungan yang terjadi tidak searah.

\section{Analisis Regresi Linear Berganda}

Analisis regresi linear berganda digunakan untuk mengetahui pengaruh atau hubungan secara linier antara dua atau lebih variabel independen dengan satu variabel dependen.Untuk garis regresi linear dengan dua variabel atau lebih prediktor persamaannya adalah sebagai berikut :

$$
\mathrm{Y}=\mathrm{a}+\mathrm{b}_{1} \mathrm{X}_{1}+\mathrm{b}_{2} \mathrm{X}_{2}+\mathrm{b}_{3} \mathrm{X}_{3}+\mathrm{e}
$$

Keterangan:

$\begin{array}{ll}\mathrm{Y} & =\text { Variabel Dependen } \\ \mathrm{a} & =\text { Koefisien Prediktor } \\ \mathrm{b}_{1} \mathrm{~b}_{2} \mathrm{~b}_{3} & =\text { Koefisien Regresi variabel independent } \\ \mathrm{X}_{1} \mathrm{X}_{2} \mathrm{X}_{3} & =\text { Subjek pada variabel independenyang mempunyai nilai tertentu } \\ \mathrm{K} & =\text { Bilangan konstan } \\ \mathrm{e} & =\text { Error }\end{array}$

\section{Uji t}

Digunakan untuk membuktikan pengaruh variabel independen terhadap variabel dependen secara individu atau parsial. Dalam pengujian ini sebelumnya dirumuskan hipotesisnya.

Ho : Variabel idependen tidak berpengaruh terhadap variabel dependen

Ha : Variabel independen berpengaruh terhadap variabel dependen

Jika Signifikansi $>0,05$ maka Ho diterima

Jika Signifikansi $<0,05$ maka Ho ditolak

4. Uji $\mathbf{F}$

Uji Anova atau uji $\mathrm{F}$ yaitu uji koefisien regresi secara bersama-sama untuk menguji signifikansi pengaruh beberapa variabel independen terhadap variabel dependen. kriteria pengujian pada Uji Anova atau Uji F ini antara lain adalah sebagai berikut :

Jika $\mathrm{F}$ hitung $\leq \mathrm{F}$ tabel maka $\mathrm{H}_{\mathrm{o}}$ diterima

Jika $\mathrm{F}$ hitung $>\mathrm{F}$ tabel maka $\mathrm{H}_{\mathrm{o}}$ ditolak

Sedangkan untuk mengetahui pengaruh simultan dari variabel berdasarkan nilai signifikansi adalah sebagai berikut :

Jika signifikansi $>0,05$ maka $\mathrm{H}_{\mathrm{o}}$ diterima

Jika signifikansi $<0,05$ maka $\mathrm{H}_{\mathrm{o}}$ ditolak 


\section{Koefisien Determinasi $\left(\mathbf{R}^{2}\right)$}

Adjusted R Square biasanya untuk mengukur sumbangan pengaruh jika dalam regresi menggunakan lebih dari dua variabel independen

\section{PEMBAHASAN}

\section{Metode Analisis Data}

1.Statistik Deskriptif

Menurut Priyatno (2014:30) "Statistik deskriptif digunakan untuk penggambaran tentang statistik data seperti min, max, mean, dan standard deviation untuk mengukur distribusi data". Statistik deskriptif berfungsi menerangkan suatu keadaan, gejala, atau persoalan. Penarikan kesimpulannya hanya ditujukan pada kumpulan data yang ada.

\section{Tabel 5}

\section{Hasil Pengujian Statistik Deskriptif}

Descriptive Statistics

\begin{tabular}{lr|r|r|r|r} 
& N & \multicolumn{1}{c}{ Minimum } & Maximum & Mean & Std. Deviation \\
\hline X1 & 80 & 35 & 65 & 53,09 & 6,271 \\
\hline X2 & 80 & 21 & 55 & 39,13 & 7,813 \\
\hline X3 & 80 & 26 & 50 & 34,93 & 5,041 \\
\hline Y & 80 & 20 & 45 & 34,63 & 5,176 \\
\hline Valid N (listwise) & 80 & & & & \\
\hline
\end{tabular}

Sumber: Hasil Pengolahan Data, 2017

Berdasarkan table 5 dapat disimpulkan bahwa Kualitas produk mempunyai nilai maksimum 65, nilai minimum 35, mean 53,09 dan standar deviasi 6,271. Harga mempunyai nilai maksimum 55, nilai minimum 21, mean 39,13 dan standar deviasi 7,813, Promosi mempunyai nilai maksimum 50, nilai minimum 26, mean 34,93 dan standar deviasi 5,041, keputusan pembelian mempunyai nilai maksimum 45, nilai minimum 20, mean 34,63 dan standar deviasi 5,176

\section{Uji Instrumen}

a. Uji Validitas

Uji validitas digunakan untuk mengukur sah atau valid tidaknya suatu kuesioner, Dimana dalam penelitian ini menggunakan tingkat kepercayaan sebesar $95 \%$ atau dengan tingkat kesalahan sebesar 5\% dengan total sampel (n) yaitu sebanyak 80 orang responden. Derajat kebebasan atau df (degree of freedom) adalah jumlah kebebasan seseorang dalam mengambil sampel. Dengan menggunakan rumus $\mathrm{df}=\mathrm{n}-2$, maka hasil df adalah $30-2=28$. Kemudian diperoleh perhitungan $r$ tabel adalah sebesar 0,374. Dasar pengambilan keputusan pada uji validitas dalam penelitian ini adalah sebagai berikut:

a. Jika $r$ hitung. $\geq r$ tabel, maka butir pertanyaan atau variabel valid.

b. Jika $r$ hitung $<\mathrm{r}$ tabel, maka butir pertanyaan atau variabel tidak valid.

\section{b. Uji Reliabilitas}

Uji reliabilitas digunakan untuk mengetahui keajegan atau konsistensi alat ukur yang biasanya menggunakan kuisioner. Maksudnya apakah alat ukur tersebut akan mendapatkan pengukuran yang tetap konsisten jika pengukuran diulang kembali. Metode yang sering digunakan dalam penelitian untuk mengukur skala rentangan (seperti skala likert 1-5) adalah cronbach alpha. Uji reliabilitas merupakan kelanjutan dari uji validitas, dimana item yang masuk pengujian dalah item yang valid saja. Uji Reliabilitas dalam penelitian ini dilakukan 
dengan menggunakan Cronbach's Alpha, yakni dengan melihat nilai Cronbach's Alpha yang diperoleh dari perhitungan melalui SPSS versi 22. berikut:

Dasar pengambilan keputusan untuk reliabilitas data pada penelitian ini adalah sebagai

a. Jika Cronbach's Alpha $\geq 0,6$, maka butir pernyataan tersebut dinyatakan reliabel.

b. Jika Cronbach's Alpha $<0,6$ maka butir pernyataan tersebut dinyatakan tidak reliabel.

Ksimpulan bahwa kualitas produk mempunyai cronbach alpha 0,849 $>0,6$ maka butiran penyataan kualitas produk reliabel, harga mempunyai cronbach alpha 0,929 $>0,6$ maka butiran penyataan harga reliabel, promosi mempunyai cronbach alpha 0,767 $>0,6$ maka butiran penyataan promosi reliabel, keputusan pembelian mempunyai cronbach alpha 0,885 $>0,6$ maka butiran penyataan keputusan pembelian reliabel.

\section{Uji Asumsi Klasik}

\section{Hasil Uji Normalitas}

Pengujian normalitas data dalam penelitian ini menggunakan uji Kolmogorov-Smirnov. Dengan membandingkan nilai signifikan yang dicapai dengan taraf signifikansi yang sudah ditentukan yaitu 0,05 . Berikut ini merupakan hasil uji normalitas

Tabel 8

Tests of Normality

\begin{tabular}{lr|r|r|r|r|r} 
& \multicolumn{3}{c}{ Kolmogorov-Smirnov } & \multicolumn{3}{|c}{ Shapiro-Wilk } \\
& Statistic & df & \multicolumn{1}{c}{ Sig. } & Statistic & df & \multicolumn{1}{c}{ Sig. } \\
\hline X1 &, 095 & 80 &, 074 &, 968 & 80 &, 045 \\
\hline X2 &, 091 & 80 &, 095 &, 950 & 80 &, 004 \\
\hline X3 &, 086 & 80 &, $200^{*}$ &, 960 & 80 &, 014 \\
\hline Y &, 087 & 80 &, $200^{*}$ &, 977 & 80 &, 158 \\
\hline
\end{tabular}

*. This is a lower bound of the true significance.

a. Lilliefors Significance Correction

Sumber: Hasil Pengolahan Data, 2017

Dari hasil pengujian terlihat bahwa signifikan yang di peroleh melebihi taraf signifikan yang telah ditentukan 0,05 sehingga menunjukkan data-data dalam penelitian ini terdistribusi normal

\section{Uji Multikolinieritas}

Uji Multikoleniaritas bertujuan untuk menguji apakah dalam suatu model regresi ditemukan adanya korelasi atau hubungan yang signifikan antar variabel bebas dimana dalam model regresi yang baik seharusnya tidak terjadi korelasi diantara variabel bebas. Pengambilan keputusan dalam uji multikolinieritas adalah dengan melihat nilai Tolerance dan VIF(Variance Inflation Factor).Berikut ini hasil uji multikololineritas :

1. Tidak terjadi multikolinieritas, jika nilai Tolerance $>0,10$.

2. Tidak terjadi multikolinieritas, jika nilai $V I F<10$.

\section{Tabel 9}

\section{Hasil Pengujian Uji Multikolinieritas}

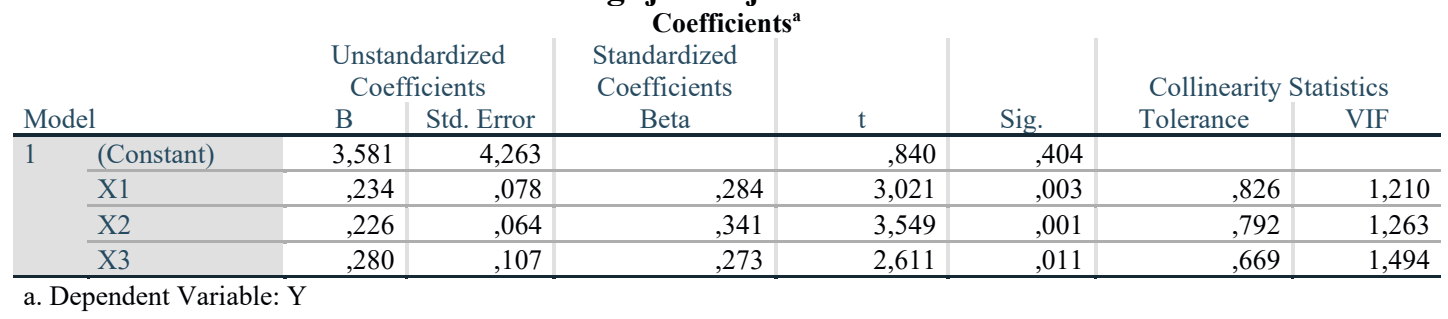


Dari hasil pengujian terlihat bahwa nilai tolerance lebih dari 0,1 dan VIF kurang dari 10 maka dinyatakan tidak multikolinieritas

\section{Uji Autokorelasi}

Pengujian autokorelasi dalam penelitian ini mengunakan uji Durbin-Watson. Berikut ini merupakan hasil uji Autokorelasi

Tabel 10

\begin{tabular}{l|l}
\multicolumn{2}{c}{ Model Summary } \\
Model & Durbin-Watson \\
\hline 1 & 1,801 \\
\hline $\begin{array}{l}\text { Sumber pengolahan data } \\
2017\end{array}$
\end{tabular}

Berdasarkan hasil pengujian diatas bahwa uji Durbin-Watson memberikan nilai DW 1.801, nilai ini akan dibandingkan dengan tabel DW dengan jumlah observasi $\mathrm{n}=80$, jumlah variabel independen $(K)=3$ dan tingkat signifikansi 0,05 dan didapat nilai $\mathrm{DL}=$ 1.5600 dan nilai $\mathrm{DU}=1.7153$. Oleh karena $\mathrm{DW}=1.801$ berarti dibawah $\mathrm{DL}=1.5600$ dan diatas 0 , Maka dari tabel dapat disimpulkan bahwa tidak ada autokorelasi.

\section{Uji Heteroskedastisitas}

Penelitian ini melakukan Uji Heteroskedastisitas dengan menggunakan Uji Scatterplot yang dibantu dengan menggunakan program SPSS versi 22. Hasil dari Uji Heteroskedastisitas dalam penelitian ini adalah sebagai berikut:

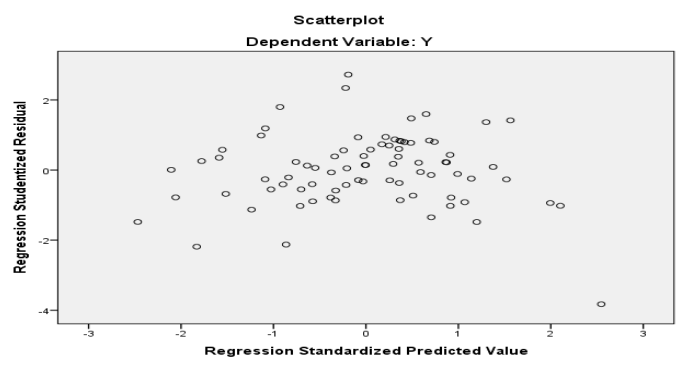

Gambar 2

Uji Heteroskedastisitas

Sumber: Hasil Pengolahan Data, 2017

\section{Analisis Korelasi}

Analisis Korelasi merupakan suatu analisis yang digunakan untuk mengetahui ada atau tidaknya hubungan yang signifikan antara variabel dependen dengan variabel-variabel independen. Teknik analisis korelasi Pearson Product Moment termasuk teknik statistik parametrik yang menggunakan data interval dan ratio dengan persyaratan tertentu

\section{Tabel 11}

Penaksiran indeks korelasi

\begin{tabular}{|c|l|}
\hline Indeks Korelasi & \multicolumn{1}{|c|}{ Penafsiran } \\
\hline $0,00-0,199$ & Sangat Rendah \\
\hline $0,20-0,399$ & Rendah \\
\hline $0,40-0,599$ & Sedang \\
\hline $0,60-0,799$ & Kuat \\
\hline $0,80-1,000$ & Sangat Kuat \\
\hline
\end{tabular}

Sumber: Sugiyono (2016:184) 
Untuk melakukan pengujiannya, kriterianya adalah sebagai berikut:

1. Jika Pearson Correlation bernilai positif, maka hubungan yang terjadi searah

2. Jika Pearson Correlation bernilai negatif, maka hubungan yang terjadi tidak searah

Tabel 12

\begin{tabular}{|c|c|c|c|c|c|}
\hline \multicolumn{6}{|c|}{$\begin{array}{c}\text { Hasil Analisis Korelasi } \\
\text { Correlations }\end{array}$} \\
\hline & & $\mathrm{X} 1$ & $\mathrm{X} 2$ & $\mathrm{X} 3$ & $\mathrm{Y}$ \\
\hline \multirow[t]{3}{*}{$\mathrm{X} 1$} & Pearson Correlation & 1 &, 137 &, $413^{* *}$ &, $443^{* *}$ \\
\hline & Sig. (2-tailed) & & ,224 &, 000 &, 000 \\
\hline & $\mathrm{N}$ & 80 & 80 & 80 & 80 \\
\hline \multirow[t]{3}{*}{$\mathrm{X} 2$} & Pearson Correlation & 137 & 1 & $453^{* *}$ &, $503^{* *}$ \\
\hline & Sig. (2-tailed) & 224 & &, 000 &, 000 \\
\hline & $\mathrm{N}$ & 80 & 80 & 80 & 80 \\
\hline \multirow[t]{3}{*}{$\mathrm{X} 3$} & Pearson Correlation & $413^{* *}$ & $453^{* *}$ & 1 &, $544^{* *}$ \\
\hline & Sig. (2-tailed) &, 000 &, 000 & &, 000 \\
\hline & $\mathrm{N}$ & 80 & 80 & 80 & 80 \\
\hline \multirow[t]{3}{*}{$\mathrm{Y}$} & Pearson Correlation & $443^{* *}$ &, $503^{* *}$ &, $544^{* *}$ & 1 \\
\hline & Sig. (2-tailed) &, 000 &, 000 &, 000 & \\
\hline & $\mathrm{N}$ & 80 & 80 & 80 & 80 \\
\hline
\end{tabular}

Berdasarkan Tabel 12 diperoleh variabel kualitas produk $\left(\mathrm{X}_{1}\right)$ mempunyai nilai $\mathrm{r}=$ 0.443 . Hal ini menunjukkan adanya hubungan positif atau searah yang sedang antara kualitas produk terhadap keputusan pembelian. Artinya, apabila kualitas produk meningkat, maka keputusan pembelian akan meningkat.

Variabel harga $\left(\mathrm{X}_{2}\right)$ mempunyai nilai $\mathrm{r}=0.503$. Hal ini menunjukkan adanya hubungan positif atau searah yang sedang antara harga terhadap keputusan pembelian. Artinya, apabila kualitas produk meningkat, maka keputusan pembelian akan meningkat.

Variabel promosi $\left(\mathrm{X}_{3}\right)$ mempunyai nilai $\mathrm{r}=0.544$. Hal ini menunjukkan adanya hubungan positif atau searah yang sedang antara promosi terhadap keputusan pembelian. Artinya, apabila kualitas produk meningkat, maka keputusan pembelian akan meningkat

\section{Analisis Regresi Linier Berganda}

Berdasarkan hasil pada tabel 13, dapat disusun persamaan Regeresi linear berganda

Tabel 13

\begin{tabular}{|c|c|c|c|c|c|c|c|c|}
\hline \multirow{2}{*}{\multicolumn{2}{|c|}{ Model }} & \multicolumn{2}{|c|}{$\begin{array}{l}\text { Unstandardized } \\
\text { Coefficients }\end{array}$} & \multirow{2}{*}{$\begin{array}{l}\text { Standardized } \\
\text { Coefficients } \\
\text { Beta }\end{array}$} & \multirow[b]{2}{*}{$\mathrm{t}$} & \multirow[b]{2}{*}{ Sig. } & \multicolumn{2}{|c|}{ Collinearity Statistics } \\
\hline & & B & Std. Error & & & & Tolerance & VIF \\
\hline 1 & (Constant) & 3,581 & 4,263 & &, 840 & ,404 & & \\
\hline & $\mathrm{X} 1$ &, 234 &, 078 & ,284 & 3,021 & ,003 &, 826 & 1,210 \\
\hline & $\mathrm{X} 2$ & ,226 &, 064 & ,341 & 3,549 & ,001 &, 792 & 1,263 \\
\hline & $\mathrm{X} 3$ & ,280 &, 107 &, 273 & 2,611 &, 011 & ,669 & 1,494 \\
\hline
\end{tabular}

a. Dependen variabel : Keputusan Pembelian

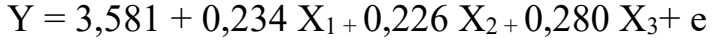

Berdasarkan tabel 13 didapatkan hasil :

1. Nilai konstanta (a) adalah 3,581; ini dapat diartikan jika kualitas produk, harga dan promosi nilainya adalah 0 , maka keputusan pembelian nilainya 3,581

2. Nilai koefisien regresi variabel Kualitas produk $\left(b_{1}\right)$ bernilai positif, yaitu 0,234; ini dapat diartikan bahwa setiap peningkatan kualitas produk sebesar 1 satuan, maka akan meningkatkan keputusan pembelian sebesar 0,234 satuan dengan sumsi variabel independen lain nilainya tetap. 
3. Nilai koefisien regresi variabel Harga $\left(b_{2}\right)$ bernilai positif, yaitu 0,226 ; ini dapat diartikan bahwa setiap peningkatan harga sebesar 1 satuan, maka akan meningkatkan keputusan pembelian sebesar 0,226 satuan dengan sumsi variabel independen lain nilainya tetap

4. Nilai koefisien regresi variabel Promosi $\left(b_{3}\right)$ bernilai positif, yaitu 0,280; ini dapat diartikan bahwa setiap peningkatan promosi sebesar 1 satuan, maka akan meningkatkan keputusan pembelian sebesar 0,280 satuan dengan sumsi variabel independen lain nilainya tetap.

5. $\quad \mathrm{e}=$ error

\section{Uji t}

Uji t (uji parsial) digunakan untuk melihat pengaruh variabel-variabel bebas secara parsial terhadap variabel terikatnya. Untuk melihat hasil pengujian dapat melihat tabel coefficient. Berikut inin hasil hitungan nilai t hitung dan taraf signifikannya dalam tabel 14untuk penelitian ini:

\begin{tabular}{|c|c|c|c|c|c|c|}
\hline & & & $\begin{array}{r}\text { Tabel } 1 \\
\text { asil Pengujia } \\
\text { Coefficients }\end{array}$ & Uji t & & \\
\hline & & Unstandardize & Coefficients & $\begin{array}{l}\text { Standardized } \\
\text { Coefficients }\end{array}$ & & \\
\hline & & $\mathrm{B}$ & Std. Error & Beta & $\mathrm{t}$ & Sig. \\
\hline 1 & (Constant) & 3,581 & 4,263 & &, 840 &, 404 \\
\hline & $\mathrm{X} 1$ & ,234 &, 078 & 284 & 3,021 &, 003 \\
\hline & $\mathrm{X} 2$ & ,226 &, 064 & 341 & 3,549 &, 001 \\
\hline & $\mathrm{X} 3$ & ,280 & 107 & 273 & 2,611 & 011 \\
\hline
\end{tabular}

a. Dependent Variable: Y

Sumber: Hasil Pengolahan Data, 2017

Menentukan $\mathrm{t}$ tabel adalah $\mathrm{df}=\mathrm{n}-2=80-2=78$. Hasil diperoleh untuk $\mathrm{t}$ tabel sebesar 1,992. Berdasarkan tabel 14 dapat disimpulkan bahwa Kualitas produk mempunyai t hitung $>\mathrm{t}$ tabel $(3.021>1,992)$ dan nilai signifikansi $0,003<0,05$ maka Ho ditolak Ha diterima artinya kualitas produk berpengaruh signifikan terhadap keputusan pembelian. Harga mempunyai $\mathrm{t}$ hitung $>\mathrm{t}$ tabel $(3.549>1,992)$ dan nilai signifikansi $0,001<0,05$ maka Ho ditolak Ha diterima artinya harga berpengaruh signifikan terhadap keputusan pembelian. Promosi mempunyai $\mathrm{t}$ hitung $>\mathrm{t}$ tabel $(2.611>1,992)$ dan nilai signifikansi $0,011<0,05$ maka Ho ditolak Ha diterima artinya promosi berpengaruh signifikan terhadap keputusan pembelian.

\section{Uji F}

Kriteria pengujian pada Uji Anova atau Uji F ini antara lain adalah sebagai berikut:

a. Jika $\mathrm{F}$ hitung $\leq \mathrm{F}$ tabel maka Ho diterima

b. Jika F hitung $>$ F tabel maka Ho ditolak

Sedangkan untuk mengetahui pengaruh simultan dari variabel berdasarkan nilai signifikansi adalah sebagai berikut:

a. Jika signifikansi $>0,05$ maka Ho diterima, tidak ada pengaruh signifikan

b. Jika signifikansi $<0,05$ maka Ho ditolak, terdapat pengaruh signifikan.

Tabel 15

Hasil Pengujian Uji F atau Anova

\begin{tabular}{|c|c|c|c|c|c|c|}
\hline \multicolumn{7}{|c|}{ ANOVA $^{\mathrm{a}}$} \\
\hline Model & & Sum of Squares & Df & Mean Square & $\mathrm{F}$ & Sig. \\
\hline \multirow[t]{3}{*}{1} & Regression & 943,141 & 3 & 314,380 & 20,359 &, $000^{\mathrm{b}}$ \\
\hline & Residual & 1173,609 & 76 & 15,442 & & \\
\hline & Total & 2116,750 & 79 & & & \\
\hline
\end{tabular}

a. Dependent Variable: Y

b. Predictors: (Constant), X3, X1, X2 
Sumber: Hasil Pengolahan Data, 2017

Berdasarkan tabel 15 diatas dapat disimpulkan bahwa $\mathrm{F}$ hitung $=20.359 . \mathrm{df}=80-2-1=$ 77. Hasil diperoleh untuk F tabel sebesar 3,115, Nilai F hitung $>F$ tabel $(20.359>3,115)$ dan nilai probabilitas (signifikan) adalah sebesar 0,000<0,05 maka Ho ditolak dan Ha diterima. Dapat disimpulkan kualitas produk, harga, promosi secara bersama-sama berpengaruh signifikan terhadap keputusan pembelian.

\section{Koefisien Determinasi}

Koefisien determinasi menunjukan seberapa besar kemampuan variabel bebas (kualitas produk, harga, promosi) dalam menjelaskan varians variabel terikat, yaitu keputusan pembelian. Dari hasil analisis regresi, dapat dilihat pada output moddel summary yang hasilnya disajikan sebagai berikut:

\begin{tabular}{|c|c|c|c|c|}
\hline \multicolumn{5}{|c|}{$\begin{array}{c}\text { Tabel } 16 \\
\text { Hasil PengujianKoefisien Determinasi }\left(\mathbf{R}^{2}\right) \\
\text { Model Summary }\end{array}$} \\
\hline Model & $\mathrm{R}$ & R Square & $\begin{array}{l}\text { Adjusted R } \\
\text { Square }\end{array}$ & $\begin{array}{l}\text { Std. Error of the } \\
\text { Estimate }\end{array}$ \\
\hline 1 &, $668^{\mathrm{a}}$ &, 446 &, 424 & 3,930 \\
\hline
\end{tabular}

Sumber: Hasil Pengolahan Data, 2017

Dari hasil output pengolahan data yang telah dilakukan, Adjusted $R$ Square menunjukkan sumbangan pengaruh variabel bebas terhadap varibel terikat. Angka ini kemudian diubah ke bentuk persen, yang artinya presentase sumbangan pengaruh variabel independen terhadap variabel terikat. Dalam penelitian ini Kualitas Produk, Harga, Promosi berpengaruh sebesar $42.4 \%$ terhadap keputusan pembelian . Dan sisanya sebesar $(100 \%-42.4 \%=57.6 \%)$ dipengaruhi oleh faktor lain yang tidak dijelaskan dalam penelitian ini.

\section{Pembahasan}

Perbandingan Hasil Penelitian dengan Teori

1. Kualitas Produk Lamer memiliki karakteristik dan fitur untuk memuaskan kebutuhan konsumen. Lamer memiliki kualitas produk yang memiliki manfaat yaitu bahan-bahan yang terbuat dari sea kelp dapat memberikan manfaat mencerahkan, melembapkan, mengencangkan, melembutkan dan dapat menghilangkan bekas luka bakar. Selain untuk merawat kuit dari dalam, kualitas yang terbaik yang ada didalam bahan-bahannya adalah melindungi kulit dari faktor lingkungan luar, seperti cuaca buruk, iklim yang berubah-ubah. Hasil penelitian menunjukkan Kualitas Produk berpengaruh terhadap Keputusan Pembeliaan, Hasil penelitian ini konsisten dengan teori yang menyatakan bahwa totalitas fitur dan karakteristik dari produk atau jasa yang dinilai kemampuannya untuk memuaskan kebutuhan konsumen, baik yang dinyatakan atau secara tersirat.Sehingga dapat disimpulkan bahwa kualitas produk dapat mempengaruhi keputusan pembelian.

2. Harga yang dibayar oleh pelanggan Lamer sebanding dengan manfaat yang diperoleh dengan menggunakan produk Lamer. Pelanggan merasa puas membeli Lamer dengan harga yang tinggi dan mendapatkan hasil yang membuat kulit menjadi lebih cerah, kencang dan sehat secara alami. Hasil penelitian menunjukkan Harga berpengaruh terhadap keputusan pembelian. Hasil penelitian sesuai dengan teori yang yang menyatakan sejumlah uang yang dibebankan atas suatu produk atau jasa atau jumlah dari nilai yang ditukar 
konsumen atas manfaat-manfaat karena memiliki atau menggunakan produk tersebut. Sehingga dapat disimpulkan bahwa harga dapat mempemgaruhi keputusan pembelian.

3. Promosi yang dilakukan Lamer adalah dengan memberikan potongan harga kepada pelanggan, memberikan facial wajah, memberikan sampel, mengumpulkan point yang berhadiah produk Lamer agar dapat mengikat pelanggan agar tetap belanja di Indonesia. Hasil penelitian ini Promosi berpengaruh terhadap keputusan pembeliaan. Hasil penelitian ini sesuai dengan teori yang menyatakan bahwa Promosi adalah cara untuk menginformasikan, membujuk dan menginginkan konsumen secara langsung maupun tidak langsung tentang suatu produk atau brand yang dijual. Sehingga dapat disimpulkan bahwa Promosi dapat mempemgaruhi keputusan pembelian.

4.

\section{Perbandingan Hasil Penelitian dengan Penelitian Sebelumnya}

Hasil penelitian ini kemudian dibandingkan dengan penelitian sebelumnya yang relevan yang telah disebutkan di bab 2 . Berikut ini hasil perbandingan hasil penelitian dengan penelitian sebelumnya.

\begin{tabular}{|c|l|l|l|}
\hline \multirow{2}{*}{ No } & \multicolumn{1}{|c|}{ Hasil Penelitian } & \multicolumn{2}{c|}{ Penelitian Sebelumnya } \\
\cline { 3 - 4 } & \multicolumn{1}{|c|}{ Konsisten } & \multicolumn{1}{c|}{ Tidak Konsisten } \\
\hline 1 & $\begin{array}{l}\text { Kualitas produk berpengaruh } \\
\text { terhadap keputuan pembelian }\end{array}$ & $\begin{array}{l}\text { Geofani Da Costa Jong } \\
(2015)\end{array}$ & $\begin{array}{l}\text { Afrianti Novita Anwar dan } \\
\text { Erpiawan (2015) }\end{array}$ \\
\hline 2 & $\begin{array}{l}\text { Harga berpengaruh terhadap } \\
\text { keputuan pembelian }\end{array}$ & $\begin{array}{l}\text { Jackson R.S Weenas } \\
(2013)\end{array}$ & Geofani Da Costa Jong (2015) \\
\hline 3 & $\begin{array}{l}\text { Promosi berpengaruh terhadap } \\
\text { keputuan pembelian }\end{array}$ & Doni Hariadi (2013) & Geofani Da Costa Jong (2015) \\
\hline
\end{tabular}

Sumber : Data diolah Penulis (2017)

\section{Penutup}

Berdasarkan hasil analisis data maka dapat di tarik kesimpulan bahwa Kualitas Produk, Harga dan Promosi mampu mempengaruhi Keputusan Pembelian Produk Kosmetik Lamer.

Saran yang bisa diberikan oleh peneliti bagi (1) penelitian selanjutnya mencari variabel lain diluar variabel independen yang peneliti gunakan untuk memastikan sebenarnya variabelvariabel apa saja yang berpengaruh terhadap keputusan pembelian. (2) perusahaan yang bergerak dibidang kosmetik harus mampu meningkatkan Kualitas Produk, mempertahankan harga, meningkatkan Promosi.

\section{DAFTAR PUSTAKA}

Griffin, W.2016. Bisnis Internasional Edisi 8. Jakarta: Salemba Empat

Gozali, Imam 2014.Aplikasi Analisis Multivariate Dengan Program IBM SPSS 23 Update PLS Regresi Edisi 8. BP : Universitas Diponegoro

Kotler,Philipdan Gary Armstrong. 2012. Prinsip-prinsipPemasaranEdisi 13. Jilid 1. Jakarta: Erlangga

Kotler, Philip dan Kevin Lane Keller.

2016. Marketing Management 15. New Jersey: Pearson.

Priyatno, Duwi. 2014. SPSS 22:

Pengolah Data Terpraktis. Yogyakarta: Andi 
Sugiyono. 2016. Metode Penelitian Kuantitatif Kualitatif dan R\&D Cetakan 23. Bandung:

Alfabeta

Tjiptono, Fandy. 2010. Strategi

Pemasaran Edisi 3. Yogyakarta: Andi

Tjiptono, FandydanGregorius Chandra.

- 2012. ManajemenStrategik. Yogyakarta: Andi

Jong, G. D. (2015). Pengaruh Kualitas Produk, Promosi dan Harga Terhadap Keputusan Pembelian Pada Produk Unggulan UMKM Di Galeri Cinderamata Surabaya. Surabaya: Junal Ekonomi.

Martoatmodjo, D. H. (2013). Pengaruh Produk, Harga, Promosi dan Distribusi Terhadap Keputusan Pembelian Konsumen Pada Produk Projector Microvision. Jurnal Ilmu dan Riset Manajemen Vol. 1 No. 1, 67-87.

Novianti, A dan Erpiawan (2015). Pengaruh Harga dan Promosi Terhadap Keputusan Pembelian Pada Toko Lily Jaya Pekanbaru. Jurnal Ilmu Manajemen Vol. 1 No. 3, hal 160-170

Weenas, J. R. (2013). Kualitas Produk, Harga, Promosi dan Kualitas Pelayanan Pengaruhnya Terhadap Keputusan Pembelian Spring Bed Comforta. Manado: Jurnal EMBA Vol. 1 No. 4, hal. 607-618. 